\title{
Вооруженное восстание в Туве в 1930 г.
}

\author{
Аяна А. Самдан \\ Тувинский институт гуманитарных и прикладных социально-экономических исследований \\ при Правительстве Республики Тыва, Российская Федерация
}

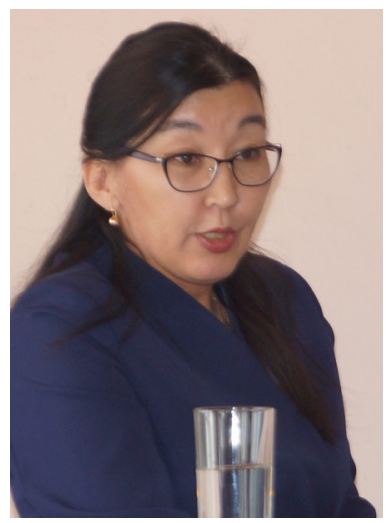

В статье осуществлена реконструкция вооруженного выступления 1930 г. в Тувинской Народной Республике на основе ранее неопубликованных архивных документов: нормативных документов органов законодательной и исполнительной власти, партийных организаций, воспоминаний участников.

В качестве предпосылок восстания названо изменение внутренней политики ТНР, которое произошло начиная с VIII съезда Тувинской Народно-Революционной партии (осень 1929 2.). Он провозгласил руководящую роль партии в управлении страной, развитие по некапиталистическому пути, отстранение от участия в государственном и общественном управлении страной бывших феодалов и чиновников. Преобразования коснулись широкого круга населения, бывшие нойоны, чиновники и ламы в большей части были ущемлены в политических и гражданских правах. Все это дало толчок к протестному движению, который принял довольно широкие масштабы. Восстание в Туве не было уникальным, смежный процесс проходил в Монголии (восстание 1930-1932 г2.), поэтому лозунги были схожи. Мятежники выступали против правительственных мер, за реставрацию прежней политической власти и буддийской религии, но конкретной программы они не разработали.

Мятежи в ТНР вспыхнули в марте 1930 г. в западных районах Тувы. Общая география восстания включила: ДзунХемчикий, нынешний Овюрский, Барун-Хемчикский, Монгун-Тайгинский, Тандынский, Пий-Хемский и Улуг-Хемский кожууны (районы) ТНР. Общее количество восставших установить не удается, есть лишь сведения по отдельным районам (примерно 400 чел.). По данным документам выясняется, что руководителями восстания выступили бывщие чиновники и состоятельные люди, но большинство составляла беднота.

Основной причиной поражения восставших стала их разрозненность. Очаги сопротивления периодически фиксировались в отдельных районах Тувы в 1931, 1932 и 1933 г2.

Ключевые слова: Тува; вооруженное восстание; история Тувы; история Монголии; Тувинская Народная Республика; тувинцы; Панчен-лама IX

\section{Для цитирования:}

Самдан А. А. Вооруженное восстание в Туве в 1930 г. // Новые исследования Тувы. 2020, № 3. С. 66-80. DOI: www.doi.org/10.25178/nit.2020.3.5

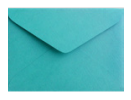

Самдан Аяна Анай-ооловна - кандидат исторических наук, ведущий научный сотрудник группы истории Тувинского института гуманитарных и прикладных социально-экономических исследований при Правительстве Республики Тыва. Адрес: 667000, Россия, г. Кызыл, ул. Кочетова, д. 4. Тел.: +7 (39422) 2-39-36. Эл. адрес: сатауапа@ mail.ru

SAMDAN, Ayana Anai-oolovna, Candidate of History, Leading Research Fellow, Group of History, Tuvan Institute for the Humanities and Applied Social and Economic Research under the Government of the Republic of Tuva. Postal address: 4 Kochetov St., 667000 Kyzyl, Russian Federation. Tel.: +7 (39422) 2-39-36. Email: camayana@mail.ru ORCID ID: 0000-0002-7785-7497 


\title{
Tuvan armed rebellion in 1930
}

\author{
Ayana A. Samdan \\ Tuvan Institute of Humanities and Applied Social and Economic Research under the Government of the Republic of Tuva, \\ Russian Federation
}

The article presents a reconstruction of an armed rebellion in 1930 in Tuvan People's Republic based on previously unpublished archival documents, including regulations issued by legislative and executive authorities, party offices and participants' memoirs.

One of the reasons for the rebellion was a change in the domestic policy of the TPR, starting from the $8^{\text {th }}$ Congress of Tuvan People's Revolutionary Party (Autumn 1929). It granted the leading role in running the country to the party, proclaimed adherence to a non-capitalist way of development, and removed former feudal lords and officials from any role in the state and public administration of the country. These transformations were felt by a broad circle of public, including former noyons, officials and lamas, who were mostly deprived of their political and civil rights. This led to the protest movement on a broad scale. The Tuvan revolt was not unique: a similar process was happening at the same time in Mongolia (culminating in the 1930-1932 rebellion), so the slogans in both countries were quite similar. The rebels rose against the government actions, supported a restoration of the former political authority and the Buddhist religion, but they failed to develop a specific program.

The riots in TPR broke out in March 1930 in the Western regions of Tuva, including Dzun-Khemchiksky, Ovyursky, BarunKhemchiksky, Mongun-Tayginsky, Tandinsky, Piy-Khemsky and Ulug-Khemsky kozhuuns (districts). The total number of rebels is difficult to specify, but it can be approximated as c. 400 people. According to the documents, they were led by former officials and the wealthy, but the rebels themselves mostly came from the poor.

The main reason for the rebels' defeat was their inability to unite. Pockets of rebellion were periodically recorded in some areas of Tuva in 1931, 1932, and 1933.

Keywords: Tuva; armed rebellion; Tuvan history; Mongolian history; Tuvan People’s Republic; Tuvans; Panchen-lama IX no. 3, pp. 66-80. (In Russ.). DOI: www.doi.org/10.25178/nit.2020.3.5

\section{Введение}

В самом начале 1930 г., в связи с изменением политического курса Тувинской Народной Республики (ТНР) при поддержке и прямом участии Коминтерна, в республике произошло крупное вооруженное восстание. В исторической литературе данный вопрос освящен в недостаточной мере, не изучен ход событий, очаги выступлений, меры, предпринятые для его подавления, а некоторые моменты в связи с переоценкой отдельных методологических установок нуждаются в переосмыслении. Кроме того, исследователи никаким образом не рассматривали связь с вооруженным восстанием в Монголии в 1930-1932 гг. Но исследования последних лет доказали, что и в Монголии и в Туве происходили смежные процессы, которые привели к вооруженному сопротивлению, а тувинское восстание не было одиночным и уникальным (см.: Кузьмин, Оюунчимэг, 2015: 132).

Научная новизна исследования состоит в том, что впервые осуществлена реконструкция вооруженного выступления в Туве 1930 г. на основе ранее неопубликованных документов. Перед автором поставлены следующие задачи, которые предстоит решить в процессе исследования: определить районы, где вспыхнули восстания; выявить социальный и имущественный состав участников восстания; установить меры, предпринятые для его подавления; изучить последствия вооруженного восстания. 
Источниковую базу, доступную в настоящее время, можно разделить на следующие группы:

- нормативные документы органов законодательной и исполнительной власти ТНР. Сюда же можно отнести приказы и постановления военных штабов и судебных органов. Они позволяют проследить деятельность государственных органов по ликвидации очагов мятежа;

- документы партийных организаций дают возможность, в частности, выявить основные проблемы, тенденции, стоявшие перед ними;

- воспоминания участников из имеющихся архивных документов. Хотя они немногочисленны, но от них можно подчеркнуть детали о ходе подавления мятежа в разных районах Тувы.

Нами привлечены документы следующих фондов Национального архива Республики Тыва (НА РТ): ф. 92 «Совет Министров ТНР», ф. 93 «Президиум Малого Хурала ТНР», ф. п. 1 «Центральный комитет Тувинской народно-революционной партии». В Научном архиве ТИГПИ (НА ТИГПИ) также хранятся важные документы по данному вопросу: записи воспоминаний участников, современников и очевидцев событий (НА ТИГПИ, д. 372 «Намчак Сат Комбуевич. Три коротких воспоминания. 1939 январь - 1941 сентябрь», на 88 л.), переводы архивных документов с монгольского языка (НА ТИГПИ, д. 1132 «1930 чылдың үймээниниң киржикчилери болгаш аңаа хамаарышкан материалдар. К. Т. Аракчаа моол дылдан очулдурган (Участники мятежа 1930 г. и материалы, относящиеся к нему. Перевел с монгольского языка К. Т. Аракчаа)), на 66 л.

\section{Историография вопроса}

В историографии исследуемой проблемы можно выделить два периода: советский и постсоветский.

Советский период характеризуется тем, что данный вопрос почти умалчивался, была обозначена лишь проблема. М. Х. Сейфулин в первом издании коллективной монографии «История Тувы» 1964 г. перечислил основные районы, где вспыхнули вооруженные мятежи и обобщил события в них. Он подчеркнул, что пропаганда мятежников о конфискации имущества всех аратов и уничтожение свободы вероисповедании в Туве «буквально совпадала с демагогической клеветой монгольских контрреволюционеров» (История Тувы, 1964: 139). Н. А. Сердобов в поддержку последнего тезиса процитировал архивный документ, где говорилось, что «группа монгольских и тувинских лам организовала штаб повстанцев в целях борьбы против правительств, в защиту религии, за уничтожение партий, за равноправие классов, против запрета отдачи детей в монастыри» (Сердобов, 1985: 98). Он подчеркнул, что переходный период от феодализма к социализму в Туве был насыщен острой классовой борьбой и тому ярким свидетельством являются вооруженные выступления 1930 г. (там же).

Авторы коллективного труда «Очерки истории Тувинской организации КПСС» (Очерки истории ... , 1975) писали, что ЦК ТНРП, руководствуясь рекомендациями Коминтерна и решениями VIII съезда, основное внимание сосредоточил на ликвидации класса феодалов. В коллективном труде описаны успехи в конфискации феодальной собственности, создании кооперативных и колхозных хозяйств. О вооруженных выступлениях 1930-1932 гг. авторы «Очерков» ни разу не упомянули, а лишь подчеркнули «ожесточенное сопротивление классово чуждых слоев населения» (там же: 86).

Таким образом, в данный период превалировала точка зрение о классовой борьбе. Соответственно, история вооруженного восстания трактовалась как пример сопротивления врагов народно-демократическому строю.

Во второй, постсоветский, период тема вооруженного восстания перестает быть табуированной. Во втором издании «Истории Тувы» (История Тувы, 2007) теме уделен специальный раздел «Вооруженные мятежи на Хемчике (1930) и в Тере-Холе (1932 г.)». В нем рассмотрены причины восстаний, лозунги мятежников, указаны представители каких сумонов принимали участие. Авторы пришли к выводу о том, что причинами вооруженных выступлений являлись «беззакония и произвол власти ТНР в отношении представителей прежней политической элиты, чиновничества, духовенства, зажиточных аратов и крестьян...» (там же: 194).

Наиболее развернуто эта тема была раскрыта в статье И. В. Отрощенко «Из истории протестного движения в ТНР первой половины 1930-х гг.» (Отрощенко, 2012), которая в большей степени опиралась на архивные документы Российского государственного архива социально-политической истории (РГАСПИ). Автор заметила, что восстания 1930 и 1932 гг. в Туве происходили одновременно с восстаниями в МНР, лозунги были идентичными, связанными именем Панчен-ламы IX (там же: 83). 
В совместной монографии С. Л. Кузьмина и Ж. Оюунчимэг утверждается, что в ответ на меры «левого курса» МНРП (1929-1932 гг.), направленные на чистку аппарата от бывших феодалов, белогвардейцев, старых чиновников, экспроприации их имущества, антирелигиозной пропаганды, возникло народное восстание в защиту буддизма и теократического строя (Кузьмин, Оюунчимэг, 2015: 15, 21). Как пишут авторы: «Одновременно с восстаниями в МНР в 1930 и 1932 гг. происходили восстания в соседней Туве, где тоже имел место “левый уклон”. Там восстания имели похожие лозунги, иногда тоже сопровождались рассказами, связанными с Панчен-ламой IX. Несмотря на контроль границы властями, были попытки взаимодействия повстанцев двух стран» (там же: 132).

\section{Предпосылки к вооруженному восстанию}

В декабре 1928 г. Коммунистический интернационал (Коминтерн) подготовил «Платформу левых», в которой критиковалась политика правых, «указывалось на неотложенность чистки рядов партии и государственного аппарата, ...укрепления центральных и местных органов партии и государственной власти работниками, способными проводить классовую линию» (Сердобов, 1985: 89). Представители Коминтерна считали, что усиление правого уклона и искажение генеральной линии партии вызывают протест широких низовых масс партии и ревсомола против политики правого государства (там же). Таким образом, Коминтерн принял непосредственное участие в выправлении линии партии. В следующем, 1929 г., Восточный секретариат Исполкома Коммунистического Интернационала (ИККИ) направил послание на VIII съезд Тувинской Народно-Революционной партии (ТНРП), в котором подчеркивалась необходимость укрепления партии и повышения ее руководящей роли, проведения социально-экономических реформ, борьбы против феодалов, теократов, ослабления влияния духовенства, широкое привлечение к укреплению государством бедняцко-батрацкие слои аратства. Данное обращение стало идейно-программным лозунгом, который следовало претворять в жизнь. Съезд, который состоялся осенью 1929 г., провозгласил генеральной линией партии развитие страны по некапиталистическому пути, и в связи с этим ставилась важнейшая задача - отстранение от участия в государственном и общественном управлении страной бывших феодалов и чиновников. Как писал в 1985 г. Н. А. Сердобов: «Дальнейшее сосуществование двух антагонистических классов в рамках одного общества ... объективно невозможно» (там же: 93).

На этом съезде был избран новый состав Центрального комитета ТНРП, куда вошли И. Шагдыржап и С. Тока. Таким образом, переворот власти в Туве произошел при поддержке и прямом участии Коминтерна, т. е. из-за вмешательства извне. Обновленный состав ЦК ТНРП принялся активно реализовывать решения съезда. В частности, был введен новый сельскохозяйственный налог, построенный на прогрессивном принципе, в результате чего 64\% аратов освободились полностью от налога, а на монастырские хозяйства устанавливалось налогооблажение.

В 1928 г. был издан закон «Об отделении религии от государства», утвержденный Малым Хуралом ТНР. Согласно данного закона, народу предоставлялось право свободного вероисповедания. Статья 1 гласила: «Тувинский народ, желающий веровать и молиться могут свободно веровать и молиться, но религия отделяется от государства» (НА РТ, ф. 92, оп. 1, д. 29, л. 14). Создавалось особое управление духовными учреждениями, которое было надзорным органом. В правление монастырей внедрялся особое лицо, в обязанность которого входил надзор за действиями лам.

В 1930 г. постановлением Президиума Малого Хурала и Совета Министров ТНР была утверждена инструкция о порядке проведения в жизнь закона об отделении церкви от государства и школ от церкви. Согласно ему, ламские общины лишались прав юридического лица и права собственности, но члены религиозной общины могли иметь свои индивидуальные хозяйства. Буддийские монастыри и их имущество были объявлены достоянием народа и поступали в ведение хошунных управлений (НА PТ, ф. 92, оп. 1, д. 352, л. 3). Власти поставили задачу национализации имущества монастырей закончить в двухмесячный срок.

Также постановлением № 4 Президиума Малого Хурала ТНР от 19.02.1930 г. запрещалось посвящение в хувраки (хуураки, т. е. учеников), присвоение духовных званий лицам и посещение молебней лицам, не достигшим 18-тилетнего возраста. Нарушение влекло за собою уголовную ответственность. Контроль возлагался на органы местного самоуправления и милицию (НА РТ, ф. 92, оп. 1, д. 352, л. 18).

Согласно статье 47 главы IV Конституции 1930 г., избирательных прав лишались:

1. лица, добывающие средства путем эксплуатации другого с целью наживы;

2. частные торговцы и ростовщики; 
3. ламы, шаманы и прочие служители религиозных культов;

4. бывшие феодалы, нойоны и чиновники;

5. бывшие руководители и организаторы контрреволюционных выступлений;

6. недееспособные лица;

7. лица, осужденные судом и пораженные в правах на определенный срок законом или судебным приговором (Основной закон ..., 1932: 13-14).

Предпринимались меры по вытеснению иностранного и частного капитала из экономики страны. Но Тувинценкооп и филиал Госторга СССР, в чьих руках сосредоточена государственная торговля, не всегда успешно справлялись со своей функцией.

Таким образом, все вышеперечисленные преобразования коснулись широкого круга населения, но, конечно, бывшие нойоны, чиновники и ламы в большей части были ущемлены в политических и гражданских правах. Все это дало толчок к протестному движению, который принял довольно широкие масштабы. Вопреки широко распространенному мнению о внешнем инспирировании восстания во главе с Панчен-ламой, как пишут С. Л. Кузьмин и Ж. Оюунчимэг, причины имели все же внутренний характер (Кузьмин, Оюунчимэг, 2015: 127).

\section{Очаги вооруженных выступлений}

Имеющиеся сведения из опубликованных работ историков и найденная, уточненная информация из архивных документов - позволили нам восстановить географию появления очагов вооруженных мятежей с марта 1930 г. в западных районах Тувы.

География распространения их была следующая: Дзун-Хемчикий, нынешний Овюрский, БарунХемчикский, Монгун-Тайгинский, Тандынский, Пий-Хемский и Улуг-Хемский кожууны ТНР (см. puс. 1).

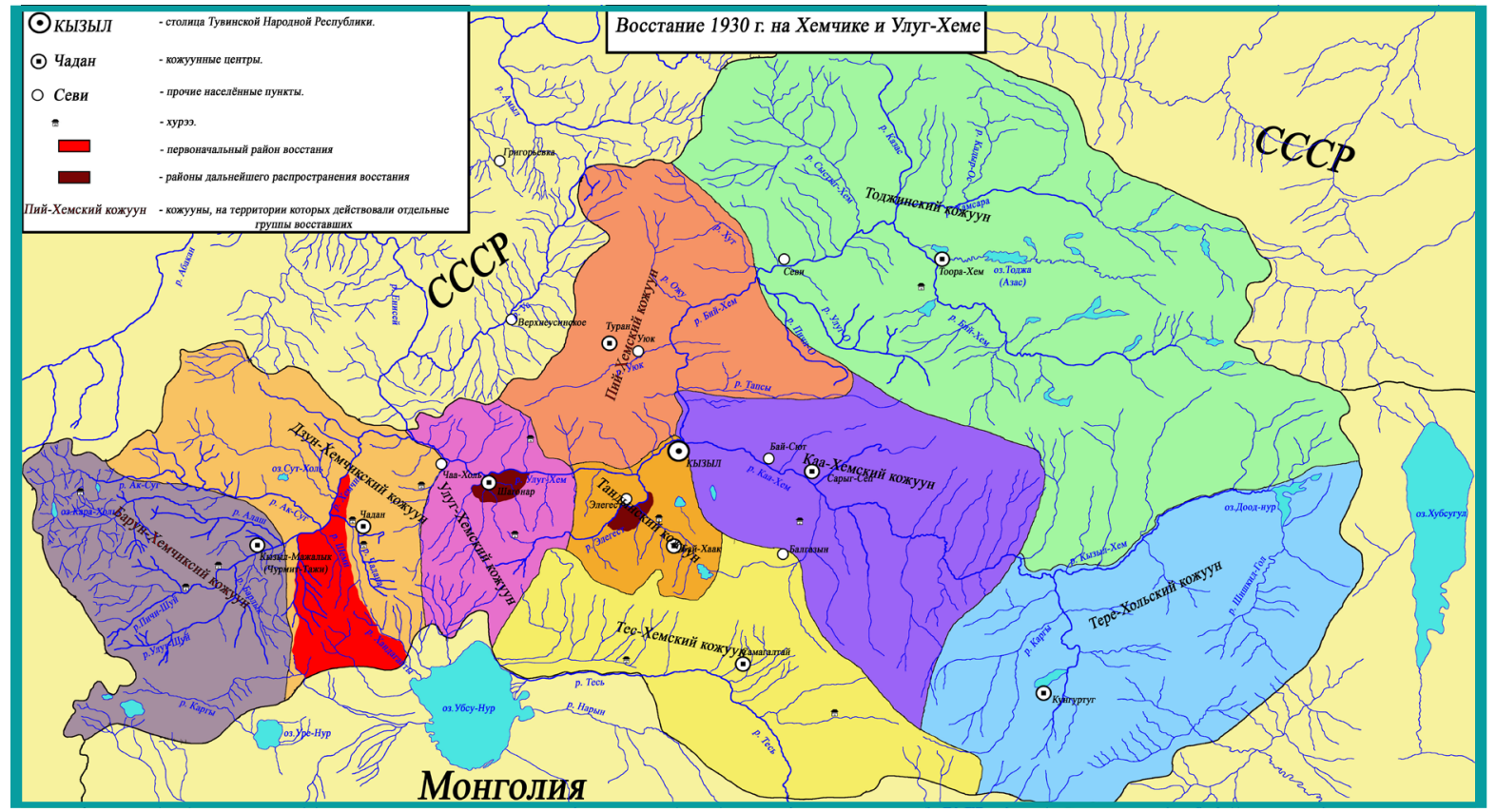

Рис. 1. Районы вооруженного восстания в Туве 1930 г.

Figure 1. Areas covered by the 1930 armed uprising in Tuva.

В западной части Тувы в протестное движение были вовлечены жители сумонов Хондергей, Шеми, Ак-Бедик, Баян-Бады, Баян-Дугай, Олзейти-Хем, Ийме, Чыргакы Дзун-Хемчикого кожууна. В последнем восставших насчитывалось 40 человек. Первым делом они освободили арестованных по политическим мотивам из тюрьмы, сняли пост на границе с целью захвата оружия и патронов. Также население нынешнего Овюрского кожууна - сумоны Хандагайты, Бора-Шай, Суме (?ำ, Саглы и Эртине-Солчур. Кроме того, действовала группа до 30 человек в Барун-Хемчике и еще меньше людей - в Монгун-Тайге.

\footnotetext{
${ }^{1}$ Идентифицировать это поселение нам не удалось.
} 
Чуть позже к вооруженному сопротивлению присоединилась центральная часть Тувы: Тандынский (сумоны Чал-Кежиг, Суг-Бажы, Кара-Булун), Улуг-Хемский (сумоны Шагаан-Арыг, Белдир-Кежиг, Арыскан, Баян-Кол, Хендерге, Торгалыг) и Пий-Хемский кожууны. В последних двух кожуунах в основном в мятеже приняли участие русское население. Они выступили с лозунгом: «Долой коммунизм - социализм, коллективизацию и непосильные налоги, да здравствует свободная торговля, свободное передвижение за границу, да здравствует буржуазное правительство» (НА РТ, ф.п. 1, оп. 1, д. 1205, л. 4). Они уничтожили 80 сажен телеграфного провода.

Поскольку ТНРА была занята ликвидацией восстания в западных районах Тувы, а «русским повстанцам ...фактически противопоставлены только маленькие отрядики из членов ВКП, пополненные некоторым количеством бывших партизан» (цит. по: Отрощенко, 2012: 76), то полномочный представитель СССР в ТНР А. Г. Старков, опасаясь более широкого участия русских, ходатайствовал о срочном вводе кавалерийского отряда из Минусинского округа (Саая, Сат, 2006: 243). Скудность архивных материалов о военном снабжении при подавлении восстания, введении советских военных сил со стороны СССР не позволяет подробно изучить данный аспект рассматриваемого нами вопроса.

Всего в восстании Пий-Хемского и Улуг-Хемкого кожуунов приняли участие 138 человек, из них 72 были осуждены Верховным Судом ТНР по статье 41 Уголовного кодекса $^{1}$ (УК), а 9 - по 45 статье УК ТНР². Но по апелляции осужденных Е. Колесникова, К. Толпышева, К. Блинова, И. Охотникова, В. Топоева, Е. Манина и М. Макарова, которые были приговорены к высшей мере наказания с конфискацией имущества, Президиум Малого Хурала ТНР своим постановлением, принимая во внимание боевые заслуги в партизанском движении Е. Колесникова и К. Блинова, заменил смертную казнь на 10 лет лишения свободы с конфискацией имущества, лишением избирательных прав на 5 лет после отбытия наказания и высылкой их за пределы республики. Остальным ходатайство о помиловании оставили без удовлетворения (НА РТ, ф. 93, оп. 1, д. 14, л. 1).

Таким образом, по доступным нам на сегодняшний день материалам, известно, что в протестном движении на Хемчике приняли участие $261\left(270^{3}\right)$ человек, а из Пий-Хема и Улуг-Хема - 138. Нет никаких сведений о количестве мятежников в Танды, поэтому общее количество невозможно установить.

В конце марта 1930 г. в приграничных с Тувой аймаках Монголии Чадмань уул (современный Увс аймак) и Хан-Тайшир (современный Завханский аймак) началось восстание (Кузьмин, Оюунчимэг, 2015: 28). Как свидетельствуют документы, один из тувинских главарей Демуртен Тулуш имел связь с одним из руководителей монгольской стороны, дорбетом Тарлу, и каждый из них должен был выступить против своего правительства (НА ТИГПИ, д. 1132, л. 32). Примерно об этом пишут С. Л. Кузьмин и Ж. Оюунчимэг: «Контрреволюционеры хотели не только уничтожить монгольскую революцию, но и ставили целью дальше уничтожать революцию в государстве Танну-Тува. Это можно увидеть по показаниям преступников Бор гэгээна, Самдана, Тугжа, Буриада, Шагдара» (Кузьмин, Оюунчимэг, 2015: 91).

\section{Лозунги мятежников}

Сведения об основных призывах мятежников содержатся в документах НА РТ, в фонде ф.п. 1, оп. 1, в делах № 885 «Документы о контрреволюционном восстании 1930 г. (на тувинском языке)», на 8 л. и № 1206 «Сведения о повстанческом движении в Туве, его характер и цели, составе участников и их семьи (по материалам обследования ЦКК ТНРП). Инструкция о переселении феодалов между хошунами и сумонами (на русском и тув. латин. языках) за 1931 г.», на 6 л.

\footnotetext{
${ }^{1}$ Ст. 41 УК ТНР: «организация вооруженных восстаний в целях нисповреждения установленного основными законами образа правления, захват власти, государственной территории, а также участие в захвате власти в центре и на местах, влекут за собой высшую меры... - расстрел, с конфискацией имущества...» (НА РТ, ф. 93, оп. 1, д. 13, л. 6).

${ }^{2}$ Ст. 45 УК ТНР: «бандитизм, т. е. организация вооруженных банд и участие в них и в организуемых ими нападениях на государственные и общественные учреждения или отдельных граждан, остановка транспорта, разрушение путей или иных средств сообщения и связи влечет за собой: лишение свободы на срок не ниже 3-х лет с конфискацией всего или части имущества с повышением при особо отягчающих обстоятельствах вплоть до высшей меры ... с конфискацией имущества» (НА РТ, ф. 93, оп. 1, д. 13, л. 7).

${ }^{3}$ В другом документе указывается 270 человек (НА РТ, ф. 144, оп. 14, д. 122 л. 4).
} 
Повстанцы проводили агитацию среди населения о том, что Панчен-Богдо (Панчын-Богда) ${ }^{1}$ с миллионным войском прибыл в Улан-Батор, а Дагданмай-камбы (Дагдан) ${ }^{2}$ с войском численностью 500 чел. - в Улясутай. Монгольская революционная партия якобы разбита. Говорили о том, что города Улан-Батор, Москва и Ленинград заняты их сторонниками, а железная дорога и морские порты находятся в руках эксплуататорского класса. «Революционная партия существует только в Кызыле. ... Монгольские и тувинские богачи везде и повсюду сплотились и сгруппировались. Не одни мы сейчас подняли восстание» (НА РТ, ф.п. 1, оп. 1, д. 1206, л. 3).

Центральная Контрольная Комиссия (ЦКК) ТНРП, после подавления восстания проанализировав лозунги, показания участников, всю ответственность возложила на Панчен-ламу $\mathrm{IX}^{3}$, который был объявлен агентом японских и китайских империалистов. Как будто бы мятежники осуществляли свои планы, держа связь с ним через Китайское бюро по монгольским и тибетским делам. Предположила, что в Туву возможно проникли лазутчики Панчен-Богдо, так же как в Монголии они были выявлены не только в восточных и западных, пограничных с Тувой аймаках, но и даже среди монгольских армейских частей (НА РТ, ф.п. 1, оп. 1, д. 885, л. 6).

Согласно выводам ЦКК, мятежники утверждали о том, что конфискации будут подвергнуты все хозяйства - бедняков и богачей; что основная цель конфискации - разорение тувинского населения; экспроприированный скот будет отдан для обеспечения голодных русских в Кызыле; власти хотят ликвидировать религию и насадить животную мораль; лишенных избирательных прав ждет смерть и ссылка за пределы страны; участники Хемчикского восстания 1924 г. ${ }^{4}$ будут убиты.

Мятежники заявляли, что у них достаточно сил, поскольку объединены с Монголией и Тибетом, а ламы совершают молебны за их победу (НА РТ, ф.п. 1, оп. 1, д. 1206, л. 4). Они агитировали, что восстановят старые порядки: вернут прежнюю административную систему и религию (НА РТ, ф.п. 1, оп. 1, д. 885, л. 4).

Таким образом, повстанцы выступали против конфискации имущества, неправильной налоговой политики, основанной на подоходно-поимущественном принципе, антирелигиозной пропаганды, в частности, отделения церкви от государства, а также проведения коллективизации аратских хозяйств, поскольку она разрушает частную собственность. Иными словами, они выступали против правительственных мер, но конкретной программы они не разработали. Но ясно лишь одно - они выступали за реставрацию прежней политической власти и буддийской религии.

Многие из этих положений совпадали с лозунгами протестовавших в Монголии: «...против подоходного налога; против конфискации имущества феодалов; за неприкосновенность монастырей, за желтую власть; против русского вмешательства в дела Монголии; против колхозов; за Панчен-ламу; за свободную китайскую торговлю. Причина была в отчаянно тяжелом экономическом положение приграничных районов, плохом снабжении товарами» (Кузьмин, Оюунчимэг, 2015: 29).

\footnotetext{
${ }^{1}$ Панчен-Богдо (Панчын-Богда) - монгольское именование Панчен-ламы, второго по рангу ламы после Далайламы в школе Гелуг тибетского буддизма. Представители этой линии перерождения (с начала XVII в.) считаются эманациями будды Амитабхи. Богдо - на монгольском языке означает «святой». Слухи о приходе Панчен-ламы распространялись не только в Туве, Бурятии и Монголии, но даже «при постройке дацана в Санкт-Петербурге (1909-1915 гг.) среди лам были слухи, что цель строительства - ...когда-нибудь приедет Панчен-лама (ПанченБогдо), который возьмет под свое покровительство 5 стран» (Кузьмин, Оюунчимэг, 2015: 127). С. Л. Кузьмин и Ж. Оюунчимэг опровергают причастность Панчен-ламы: «Предпосылки появления в МНР Панчен-ламы рассматривались повстанцами как такая же реальность, как начало Шамбалинской войны или как указанные выше магические средства. Говорить о том, что восстание было инспирировано Панчен-ламой или японцами столь же неверно, как говорить о том, что оно инспирировано, например, Шамбалой» (там же: 171).

${ }^{2}$ Дагданмай-камбы (Дагдан) - тувинский буддийский служитель, сторонник присоединения Тувы к Монголии, близкий соратник М. Буян-Бадыргы, в самом начале 1930 г. эмигрировал в Монголию (Монгуш, 2001: 110-111). ${ }^{3}$ Панчен-лама IX Тубтен Чокьи Нима (1883-1937) - тибетский религиозный деятель, был вынужден покинуть Тибет из-за новой системы налогооблажения в 1923 г. Повстанцы крупнейшего восстания в Хубсугульском аймаке 1932 г. называли себя «желтыми воинами», то есть воинами буддизма школы Гэлуг, а «некоторые отряды назывались «солдаты Панчен-Богдо»» (Кузьмин, 2016: 228).

${ }^{4}$ Хемчикское восстание началось 11 марта 1924 г. Возглавил Куулар Сумунак, который объявил себя ханом Хемчика. Основная цель - реставрация старого строя и присоединение Тувы к Монголии (История Тувы, 2007: 153).
} 


\section{Меры Правительства ТНР}

17 марта 1930 г. состоялось заседание Политбюро, где в повестке дня стоял один вопрос: «Об оценке восстания в Дзун-Хемчике». На заседании присутствовали И. Шагдыржап, С. Чурмит-Дажы, Т. Ш. Сат, О. Танчай, С. Лопсан, С. Бульчун, Хемчик-оол, Т. Седип-оол и Аюшин. С основным докладом выступил С. Бульчун (НА РТ, ф.п. 1, оп. 1, д. 843, л. 17).

Постановили немедленно ликвидировать этот бунт, для этого необходимо не только усилить боеспособность армии, но и работу Управления Государственной Внутренней Политической Охраны (УГВПО), провести мобилизацию среди членов партии и ревсомола и разъяснительную работу среди населения, а также организовать Штаб внутренней обороны страны, в состав которого вошли первые лица государства: И. Шагдыржап (председатель), С. Чурмит-Дажы, С. Лопсан и главный военный инструктор В. И. Конюшевский. Данному штабу подчинялись штаб Тувинской народно-революционной армии (ТНРА), дислоцировавшийся в Чадане, и полевые военные штабы на местах.

На следующий день, 18 марта, состоялось уже заседание Штаба обороны страны, в котором постановили увеличить число лошадей уртонов ${ }^{1}$, с целью улучшения сообщения между ними; караулы военных складов, тюрьмы и города укрепить армейцами. Также было решено для усиления отделения УГВПО в Тесингольском кожууне отправить 5 народоармейцев (НА РТ, ф.п. 1, оп. 1, д. 843, л. 15). Затем Штаб передислоцировался в Чадан.

Приказом И. Шагдыржапа, ответственным командиром всех отрядов был назначен инструктор Н.И.Свиридов. «...т. Свиридов - говорилось в приказе № 4 от 28 марта 1930 г., - приступает к исполнению обязанностей ответственного командира всех отрядов и информирует о ходе военных операций армии против бандитов» (НА РТ, ф.п. 1, оп. 1, д. 843, л. 19). Но данное решение было ошибочным, поскольку, на деле оказалось, что языковой барьер между командиром и подчиненными не позволял точно и своевременно выполнять команды. Это же признавал и он сам: «Назначение меня командующим группой - писал Н. И. Свиридов, - ...не вполне желательно....Встречаются затруднения в управлении, т. к. не знаю тувинского языка и команд, а переводы вызывают только излишние разговоры» (там же: л. 21). Н. И. Свиридов, как инструктор, должен был анализировать оперативную ситуацию и давать указания, а не стремиться непосредственно принимать участие в боевых действиях.

Чтобы предотвратить перемещение мятежников из одного населенного пункта в другой, тем самым, не давая им объединяться, были установлены посты на границах кожуунов и на перевалах. Так, на границе Монгун-Тайги и Овюра в м. Чигитей патрулировали 10 человек, в Каргы - 14, Моген-Бурене 12 (НА ТИГПИ, д. 1132, л. 48).

В конце марта 1930 г. в Барун-Хемчике из-за усиления повстанческого движения в Овюре, установили посты на границе с кожууном на трех перевалах: Хургумнуг (Хугурум, Хугерем, Хургум, Хургем) на Саглы, Арзайты на Барлыке по 17 человек, а на перевал Харый (Халый) были отправлены 20 человек из сумона Аянгаты. Согласно приказа № 7 от 30 марта 1930 г. начальника полевого штаба Шыырапа, посты должны были стоять с 31 марта по 10 апреля 1930 г. А в самом центре Барун-Хемчика дислоцировался отряд из 36 цириков ${ }^{2}$ (НА РТ, ф.п. 1, оп. 1, д. 882, л. 1-2).

В середине апреля из Барун-Хемчика были отправлены 30 цириков, вооруженных берданками, для установления поста около р. Каргы.

В столице был введен комендантский час, который отменили с 15 апреля 1930 г., а спецпропуска выписывал Штаб (НА ТИГПИ, д. 1132, л. 26).

\section{Социальный и имущественный состав восставиих на Хемчике}

Согласно данным ЦКК ТНРП, которые есть в фонде ф.п. 1, оп. 1, дд. 885 и 1206 НА РТ, в отдельной части восстания - на Хемчике - принял участие 261 человек, из них, как указано в документе, более 30\% составили молодые люди

Из числа руководителей восстания членом партии был Оолакай чалан, бывшими чиновниками Тамдыкай чалан, Лопсан Куулар демчи, Алдын-Херел Кара-Монгуш хунду и лама - Шыырап Монгуш хелин.

\footnotetext{
1 Уртон - почтовая станция.

${ }^{2}$ Цирик (от монг. čerig) - рядовой боец, солдат армии Тувинской Народной Республики, народоармеец.

${ }^{3}$ В документе не был указан возраст этих людей.
} 
Имеющиеся сведения на восставших позволили нам сгруппировать участников и составить диаграмму (см. диагр. 1). Она показывает, что более половины участников $-54,4 \%$ составляют беспартийные; 30,6\% - бывшие феодалы, чиновники, ламы и шаманы; 14,9\% - члены партии и ревсомола.

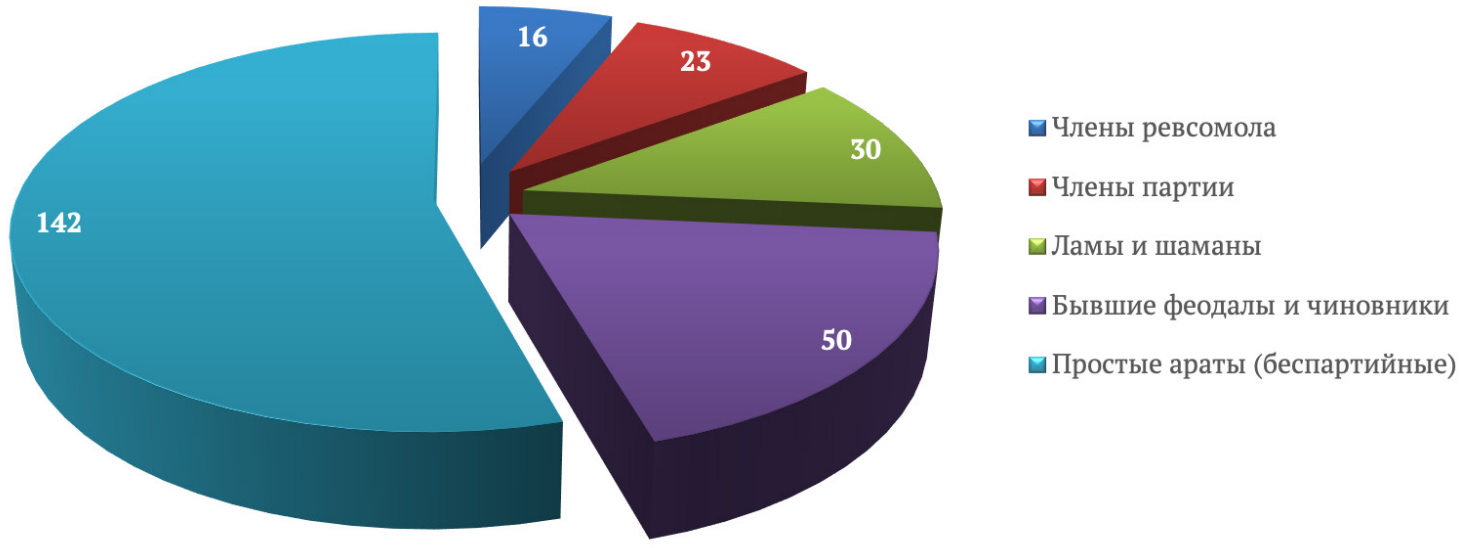

Диаграмма 1. Социальный состав мятежников восстания в Туве 1930 г. Diagram 1. Social composition of rebels in the 1930 Tuva uprising.

Участие простых аратов оправдывалось тем, что их заставляли, им угрожали пытками и истязаниями, или же тем, что присоединились по несознательности. Часть из них являлись выходцами из «чуждой» среды, были деклассированы.

Члены ревсомола и партии - это «примазавшие» элементы из числа бывших чиновников, лам и шаманов, которые «присосались к партии» (НА РТ, ф.п. 1, оп. 1, д. 1206, л. 6).

В ТНР до введения собственной денежной системы основным платежным инструментом, как в дореволюционной Туве, служил скот, и соответственно, налог взымался в бодо ${ }^{1}$ (История Тувы, 2007: 178).

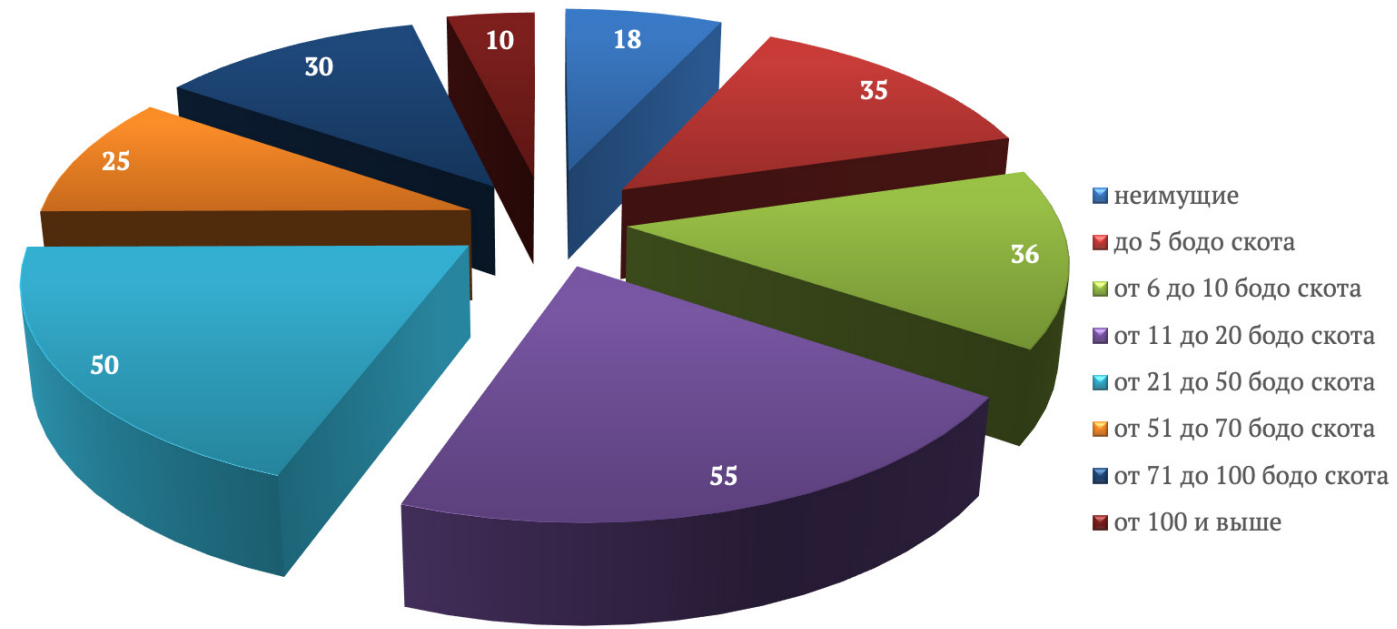

Диаграмма 2. Состав восставщих в Туве 1930 г. по имущественному положению. Diagram 2. Rebels in the 1930 uprising by family wealth.

В. Мачавариани, который побывал в Туве в конце 1928 г. - начале 1929 г. по линии Коммунистического Интернационала Молодежи (КИМ), дал следующий расклад имущественного положения:

${ }^{1}$ Бодо - условная единица для исчисления скота. 1 бодо равен 1 голове крупного рогатого скота или лошади, или 10 овцам, или 20 козам. 
- до 20 бодо имел бедняк, он вынужден был батрачить;

- от 20 до 80 бодо - маломощный середняк, еле-еле сводящий концы с концами;

- от 80 до 120 - зажиточный середняк;

- от 150 до 300 - кулак (Мачавариани, Третьяков, 1930: 54-55).

Руководителями восстания на Хемчике выступили бывшие чиновники и состоятельные люди. Так, Шыырап Монгуш хелин имел 65 бодо, Тамдыкай-чалан - до 60 бодо, Тавакай - 30 бодо, Алдын-Херел Кара-Монгуш - 119 бодо, Алдын-Херел Куулар - 62 бодо, Лопсан Куулар демчи - 129 бодо, Демуртен Тулуш ${ }^{1}$ - 171 бодо, Оолакай-чалан - до 100 бодо. Состоятельная часть восставших раздавала населению скот и вещи бедным. Население сочувственно относились к ним и информировало о продвижении отряда.

Из составленной нами диаграммы № 2 видно, что менее 25\% участников имеют от 71 и выше бодо скота, а большинство относится к бедному и среднему сословию населения.

\section{Боеспособность вооруженного объединенного отряда народоармейцев}

Из рапортов, донесений, сводок командиров штабов, хранящихся НА РТ, ф.п. 1, оп. 1, д. 843 «Постановления Политбюро ЦК ТНРП и Штаба обороны страны по ликвидации восстания на Хемчике, рапорты, донесения и другие материалы Штаба обороны страны (на русском языке) за 1930 г.», на 26 л., можно узнать о материальной обеспеченности правительственного отряда.

17 марта 1930 г. для подавления восстания был отправлен отряд Тувинской народно-революционной армии (ТНРА), который состоял из 100 цириков вместе с командно-политическим составом. Но отряд совершенно не был обучен командно-тактической работе, не имел опыта ведения военных действий, в связи с этим возникали большие затруднения во время боя управления народоармейцами. Даже в отдельных случаях среди них возникала паника. С первыми выстрелами цирики просто разбегались, были зафиксированы случаи оставления мест боевых действий, как например, в Овюре после операции почти половину цириков не досчитались (НА РТ, ф.п. 1, оп. 1, д. 843, л. 11).

К отряду присоединились добровольцы в количестве 80 чел., которые не имели никакой военной подготовки. Объединенный отряд, в основном, был расквартирован по юртам местного населения, но все же многим из них приходилось холодные весенние ночи проводить под открытым небом. Также случались перебои с питанием и сезонной одеждой. Половина винтовок цириков находилась в неудовлетворительном состоянии. Все это влияло на моральное состояние цириков (НА РТ, ф.п. 1, оп. 1, д. 843, л. 11).

Кроме того, в условиях многодневного перехода по горным местностям лошади отряда истощились, а заменить их не было возможности, поскольку у аратов местностей, которые проходил отряд, не имелось большого количества табуна. Конское снаряжение правительственного отряда казенного образца также не подходило для местной породы лошадей. Большие трудности были и с их кормлением. Из-за большого покрова снега подножный корм местами отсутствовал, и приходилось делать остановки длительностью до шести часов, чтобы дать им время на пастьбу, что влияло на маневренность отряда. В результате после восьми дней экспедиции отряд мог передвигаться только по 10 км/час (НА РТ, ф.п. 1, оп. 1, д. 843, л. 10).

Со своей стороны народоармейцы допускали бесчинства по отношению к родственникам мятежников, при разъяснении генеральной линии партии, повышении сознательности масс применяли пытки, избиения, а также насильно переселяли их в другие места. Так, в Бора-Шае, Хондергее, Шеми и Чыргакы члены отряда разграбили юрты, забирая имущество, арестовали, не принимая во внимание виновность и невиновность аратов, допрашивали их с применением физической силы. Даже был зафиксирован случай отрезания ушей Алдын-Херелу и демонстративного показа их с целью устрашения (НА РТ, ф.п. 1, оп. 1, д. 843, л. 14).

В Аянгаты члены партии, по сообщению восставших, учиняли несоответствующие уставу партии действия, - силой снимали кольца с пальцев с женщин и девушек и даже насиловали их. «На такие безобразные вещи, - указывали в своем послании мятежники, - соответствующие организации со-

${ }^{1}$ Демуртен Тулуш и Лопсан Куулар были арестованы правительственным отрядом на верховьях г. Баян-Чурек за р. Саглы 17 апреля 1930 г. (НА ТИГПИ, д. 1132, л. 40). 
вершенно не обращают внимания. Мы очень удивляемся» (Отрощенко, 2012: 78). Они утверждали, что именно действия, когда пугали, заставляли страдать незамужних женщин, а также отрезание ушей Алдын-Херелу стали отправной точкой для поднятия восстания (НА ТИГПИ, д. 1132, л. 28).

Эти факты стали известны Штабу и 28 марта 1930 г. И. Шагдыржап издал приказ на имя комиссара армии и командиров отрядов об их ответственности за допущение бесчинств, избиения со стороны народоармейцев. «Необходимо... следить, - говорилось в приказе, - за действиями и поведением красноармейцев и сохранением дисциплины среди них» (НА РТ, ф.п. 1, оп. 1, д. 843, л. 19).

\section{Военные действия в западных кожуунах Тувы}

Ход военных действий можно восстановить по документам из НА РТ, ф.п. 1, оп. 1, д. 843 «Постановления Политбюро ЦК ТНРП и Штаба обороны страны по ликвидации восстания на Хемчике, рапорты, донесения и другие материалы Штаба обороны страны (на русском языке) за 1930 г.», на 26 л. и НА ТИГПИ, д. 1132 «Участники мятежа 1930 г. и материалы, относящиеся к нему. Перевел с монгольского языка К. Т. Аракчаа», на 66 л.

В середине марта 1930 г. группа восставших в количестве 50 человек из Чыргакы, Шеми и Овюра выехали в Чадан, намереваясь арестовать партийных работников и добыть оружие, но, никого не застав, освободили из тюрьмы 50 арестованных. После часть людей разошлась по своим аалам, но основной костяк ушел в м. Бора-Шай. По дороге они нередко под угрозой вынуждали население присоединиться к ним и оказывать им помощь. В Бора-Шае мятежники вступили в бой с правительственным отрядом. После непродолжительной перестрелки мятежникам удалось уйти, и они засели в тайге за р. Саглы (НА ТИГПИ, д. 1132, л. 31).

27 марта 1930 г. около 11 часов в 10 км от пограничного поста в Овюре правительственный отряд внезапно был обстрелян восставшими, что вызвало панику среди них. Первыми выстрелами был убит ревсомолец Н. Малинин. Командиру понадобился час, чтобы остановить панику и отправить разведку. Затем отряду удалось занять высоту, потеряв при этом 1 человека и один раненный впоследствии умер. Таким образом, были убиты всего 3 человека. Бой продолжился до наступления темноты. Оставив ночной караул, отряд ушел на ночлег. Ночью патруль вел редкую перестрелку. Ему удалось поймать одного перебежчика. Во время допроса удалось узнать о количестве повстанцев -25 человек, а число главных руководителей - 3. Вооружены трехлинейными винтовками (11 шт.) и кремневыми ружьями (HA PT, ф.п. 1, оп. 1, д. 843, л. 13). Они напали на пограничный пост, где добычей стали 3 винтовки и патроны к ним.

28 марта 1930 г. в 4 часа утра около 20 восставших, вооруженных трехлинейной винтовкой Мосина и кремневыми ружьями, угнав свой скот, пересекли границу и ушли в Монголию. Всего в Монголию ушли 512 тувинцев, вместе с юртами и скотом, 80 из них были вооружены (Отрощенко, 2012: 75). За ними отправлены два разъезда по 25 человек, но они вынуждены были остановиться около границы (НА РТ, ф.п. 1, оп. 1, д. 843, л. 20). В Штаб доложили, чтобы тувинские власти договорились с соответствующими органами Монголии о совместном проведении операции по поимке «бандитов» (там же: л. 24).

Оценив ситуацию, когда люди и лошади находились в физическом и моральном истощении, было принято решение временно отступить в Чадан, чтобы привести их в боевое состояние, а на месте оставить 50 цириков и 10 человек из добровольцев, хорошо знающих данный район (НА РТ, ф.п. 1, оп. 1, д. 843, л. 21).

6 апреля 1930 г. в м. Кашпал и с. Бора-Шай была отправлена группа разведки в количестве 21 цирик. Но она ничего не обнаружила, лишь смогла поймать одного из числа восставших, которого перенаправили в Чадан. Отсюда были посланы 2 человека в с. Бора-Шай, но они также никого не обнаружили (там же).

Для того, чтобы узнать положение в соседней Монголии, на границу был отправлен посыльный, который сообщил, что служители монастыря Тогс-Буянт устроили бунт. Ламы имели связь с тувинскими мятежниками. Монгольские власти для его подавления прислали военные силы. Также он сообщил, что тувинские мятежники, которые перешли монгольскую границу направляются в м. Зеленый Хорагай (НА ТИГПИ, д. 1132, л. 36).

По дороге домой группа, заезжая в аалы аратов, заставляла оставлять свои исконные места кочевания и переселятся в с. Хандагайты (НА РТ, ф.п. 1, оп. 1, д. 843, л. 21).

Для подавления мятежа в Барун-Хемчике были мобилизованы 100 человек из числа партийно-ревсомольского состава, которых отправили в район Шеми (НА РТ, ф.п. 1, оп. 1, д. 843, л. 19). 
3 апреля 1930 г. полевой штаб в Барун-Хемчике принял решение уменьшить количество цириков на постах из-за расходов по содержанию. Так, на посту Харый оставлены 15 цириков, на перевалах Хургумнуг (Хугерем) и Арзайты - по 10, а в центре - 10. Этим быстро воспользовались повстанцы (НА PT, ф.п. 1, оп. 1, д. 882, л. 5). 7 апреля 1930 г. они напали на пост на верховьях Барлыка. Народоармейцы использовали весь имеющийся запас патронов и вынуждены были отступить и остановиться в м. Шын. Повстанцам удалось не только занять пост, но и взять в плен двух цириков. После туда была направлена разведка из правительственного отряда из четырех человек. Она доложила о скоплениях людей в м. Харый, Сарат, Огагаг Харый (там же: л. 9).

После этого случая, снова численность людей на постах в перевале Хургем и м. Шын была увеличена до 30 цириков (НА РТ, ф.п. 1, оп. 1, д. 882, л. 14).

12 человек из Монгун-Тайги отправились, чтобы объединиться с овюрцами. Навстречу им были направлены народоармейцы из Барлыка. Мятежникам пришлось ретироваться, но их догнали и всех арестовали, затем доставили в штаб в Чадане (НА РТ, ф.п. 1, оп. 1, д. 882, л. 4, 9).

\section{Попытки переговоров}

В фондах НА РТ, ф.п. 1, оп. 1, д. 843 «Постановления Политбюро ЦК ТНРП и Штаба обороны страны по ликвидации восстания на Хемчике, рапорты, донесения и другие материалы Штаба обороны страны (на русском языке) за 1930 г.», на 26 л. и НА ТИГПИ, д. 1132 «Участники мятежа 1930 г. и материалы, относящиеся к нему. Перевел с монгольского языка К. Т. Аракчаа», на 66 л. хранятся переводы писем мятежников со старописьменного монгольского языка.

Восставшие делали попытки вступления в переговоры путем отправки посыльных с письмами с основной целью - избежать вооруженного столкновения и кровопролития. В них они каждый раз давали понять, что они не хотят насилия и их действия не направлены против правительства. Так, в одном из посланий было написано:

«Упорно ходят разговоры из уст самих членов партии, что будут убиты или высланы за пределы границы люди. Мы не стоим на защите богатых и не против народно-революционной партии... Поскольку уничтожены религия и монастыри, а также будут лишены (избирательных. - А. С.) прав оставшиеся невинные несколько зажиточных людей и ламы, аннулируется право собственности и самое горькое - они будут высланы за пределы страны или убиты, то наша цель - вступить с вами в переговоры с надеждой хоть каким-то образом смягчить им условия» (НА ТИГПИ, д. 1132, л. 29).

В другом письме они сообщали, что они целились не в народоармейцев, а в лошадей, «ибо среди вас есть цирики, которые имеют среди нас своих родителей» (НА РТ, ф.п. 1, оп. 1, д. 843, л. 14).

Араты Овюра два раза передавали послания. В первом послании указали, что «...новые мероприятия партии и правительства имеют большие недостатки, не соответствуют Основному закону» республики. Реально оценивая свои силы, они обратились к правительственному отряду не вступать с ними в вооруженный конфликт (НА РТ, ф.п. 1, оп. 1, д. 843, л. 9).

В ответ был выставлен ультиматум собрать и сдать свое оружие 23 марта 1930 г. в 16 часов у юрты Алдын-Херела Кара-Монгуш, который проживал на границе Чаданы и Шеми, а также явиться самим, чтобы «договориться о быстрой ликвидации возникшего недоразумения» (НА РТ, ф.п. 1, оп. 1, д. 843, л. 9). «Если с вашей стороны появятся новые попытки противиться, - писали в ответном обращении, то мы будем жестоко карать вас, как бандитов» (там же). Но когда мятежники по их требованию отправились к указанному месту, то они разминулись с правительственным отрядом.

На второе послание ответ был дан заместителем председателя Правительства О. Танчаем, в котором он потребовал прекратить свои противоправные действия, которые мешают аратам мирно строить свое хозяйство. «Вы уже своими действиями доказали, что являетесь защитниками интересов феодалов и богатеев, ставите своей задачей борьбу с революцией, что должно повлечь за собой жесточайшее наказание по характеру содеянных преступлений» (НА РТ, ф.п. 1, оп. 1, д. 843, л. 16). Далее предлагалось не позднее 1 апреля 1930 г. сдать оружия в с. Чыргакы. В случае невыполнения их ожидает конфискация всего имущества, арест членов семьи, а их самих «переловят и уничтожат» (там же).

Таким образом, мятежники пытаясь избежать прямого столкновения и, соответственно, кровопролития, хотели договориться, но все действия мятежников оценивались правительственными кругами как выступления против трудового народа ТНР и намеченных преобразований в области экономики и культуры. 


\section{Выступление в Танды}

В рукописной фонде НА ТИГПИ за № 372 хранится воспоминание Сата Комбуевича Намчака, полномочного представителя ТНР в СССР в 1938-1941 гг., непосредственного участника событий 1930 года. В том году он служил старшиной ТНРА.

Согласно этому документу, в апреле месяце стало известно о появлении небольших вооруженных групп в Танды. 29 апреля был убит директор и крестьянин госхоза «Элегест».

В сумоны Суг-Бажы и Кара-Булун были отправлены 17 человек. В основном, по воспоминаниям С. К. Намчака, группа состояла из русских. На месте они разделились на две части. Командирами были назначены Семен Коровин и Турков.

30 апреля рано утром в Суг-Бажы они смогли остановить группу из 9 вооруженных всадников. А другому отряду, направленный в Кара-Булун, менее повезло. Сначала он смог поймать 6 вооруженных мятежников. Их закрыли в здании школы, оставив сторожить Павла Дармаина. А остальные пошли обедать. В помощь мятежникам пришли их сообщники, обезвредив сторожа, взяв его винтовку, открыли дверь школы и вместе убежали в лес.

В начале мая из Кызыла и Бай-Хаака была прислана подмога. 10 мая 1930 г. С. Коровин, взяв только 20 человек, двинулся в сторону оз. Чагытай в поисках сбежавших. Они обошли все населенные пункты Танды.

За весь период состоялись две коротких перестрелки: около с. Марачевка и в верховьях р. Шуурмака. В последнем случае ночью 28 мая в верховьях р. Шуурмака отряд был внезапно обстрелян мятежниками. Последние также внезапно исчезли, как появились. Затем они, в основном в ночное время, направились в сторону Овюра, чтобы объединится с ними. Но после перевала на Торгалыге встретились с правительственным отрядом, в результате чего один был ранен, а все остальные были арестованы (НА ТИГПИ, д. 372, л. 60-74).

Как видно из документов, русское население Пий-Хема и Улуг-Хема действовали объединено. В основном они совместно действовали в центральной части Тувы, т. е. Улуг-Хеме и Танды.

\section{Работа над ошибками}

В НА РТ, ф.п. 1, оп. 1, д. 1070 «Постановления и резолюции Президиума ЦК ТНРП и ГК ТНРП о демагогических выступлениях чести делегатов Великого Хурала против политики правительства ТНР и его руководителей, о работе учреждений и предприятий ТНР и по персональным докладам членов ТНРП, практические предложения об обследовании хошунных парторганизаций, протокол № 1 заседания комиссии по организации Тувгоскино и протоколы ТЦК (на русском языке) за 1930-1931» на 60 л. имеется сведения о результатах ревизий парторганизаций и об основных выводах контрольных органов ТНР.

После подавления восстания, в каждом кожууне, где вспыхивали мятежи, по линии ТНРП была проверена работа парторганизаций. Во время проверки работы Барун-Хемчикской хошунной парторганизации выяснилось, что при проведении антирелигиозной работы секретарь хошкома ревсомола тов. Домда «грубо искривлял партийную линию (отбирал предметы культа, допрашивал лам и шаманов, применяя угрозы к ним, открыто оскорблял чувство верующих и т. д.), что вызвало недовольство беспартийных масс работой парторганизации и ревсомола» (НА РТ, ф.п. 1, оп. 1, д. 1070, л. 14-15). По результатам проверки, Домда был исключен из рядов партии, а председателю хошунной парторганизации Лопсану объявлен выговор.

В целом, проверяющие подчеркнули необходимость усиления работы в социальной и культурнопросветительской сферах, но основное внимание местных партийных и ревсомольских организаций должно быть направлено на развитие земледелия и скотоводства.

Во время избирательной компании, в нарушение закона, были лишены прав люди престарелого возраста, с криминальным прошлым, пьяницы или же по таким мотивам, как «неисполнение порученных работ, утайка скота» и др. (НА РТ, ф.п. 1, оп. 1, д. 1070, л. 13).

Подобные замечания были высказаны по Улуг-Хемской, Каа-Хемской и Дзун-Хемчикской парторганизациям.

ЦКК ТНРП проанализировала причины, ход восстания, лозунги, социальный и имущественный состав мятежников и сделала соответствующие выводы, которые были озвучены в июне месяце на 
Пленуме ЦК ТНРП и Пленуме ЦКК ТНРП. В своих выводах они подчеркнули тот факт, что подготовка к вооруженному восстанию прошла незаметной, что свидетельствует о слабой работе партийных и административных органов, а члены ревсомола и партии не могут в короткий срок мобилизоваться из-за отсутствия военной подготовки.

Также отметили, что «искривления» линии партии в практической работе (при проведении выборов, конфискации имущества, антирелигиозной работы и др.) дали возможность активироваться и использовать в своих интересах бедняков феодально-теократическим элементам (НА РТ, ф.п. 1, оп. 1, д. 1206, л. 6).

В резолюции Пленума ЦК и ЦКК ТНРП, состоявшегося в июле 1930 г., говорилось о недопустимости «администрирования нарушений принципа добровольности вступления аратов в коллективные хозяйства» (цит. по: Очерки истории ..., 1975: 86). Решено было внедрять простейшие формы хозяйственной кооперации в виде товариществ по закупке машин, племенных производителей, обработке земли, разведению скота и др. Многие не были готовы вступать в колхозы, просто самоуничтожали, дробили и отдавали близким родственникам свой скот. Также это было связано с высокими налогами. Житель сумона Хондергей Дзун-Хемчикского кожууна Бальчин в 1929 г. имел более 70 голов скота, а по переписи 1930 г. он указал только 40 (НА РТ, ф. 93, оп. 1, д. 1070, л. 35).

Как уже выше говорилось, ЦКК ТНРП внешним организатором и идейным вдохновителем назвала Панчен-ламу IX, а планы последнего в Монголии и Туве реализовали феодальные элементы. С. Л. Кузьмин и Ж. Оюунчимэг в своей монографии «Вооруженного восстание в Монголии в 1932 г.» убедительно доказали, что Панчен-лама в это время был больше занят реставрацией своего права в Тибете (см.: Кузьмин, Оюунчимэг, 2015: 127-161).

\section{Заключение}

Вооруженное восстание в Туве в 1930 г. захватило большую часть территории страны и является одним из крупных в XX в. VII Великий Хурал (1930 г.) одобрил «левый курс» линии партии. Предполагалось активное наступление власти на религию. Поэтому проведение конфискации имущества бывших феодалов и чиновников, лам и шаманов, которое на местах приобретало несколько изощренный вид, когда применялись физическая сила и моральное запугивание и др. - все эти факторы привели к росту протестного настроения.

Движущими силами вооруженного восстания 1930 г., как показывают собранные материалы ЦКК, в отличие от их утверждения, явилась беднота, имеющая менее 50 голов скота.

Основной причиной поражения восставших стала их разрозненность. Каждая группа действовала под свой лад, а также была не опытна в военном деле. Они нападали на местные органы власти, пограничные посты, старались не задерживаться на одном месте, совершали набеги и уходили в горы. У них не была разработана программа и не выдвигались никаких требований правительству. Среди руководителей восстания не нашлось яркой личности, которая объединила бы всех их.

Правительственный отряд действовал с переменным успехом в подавлении восстания, но в отдельных случаях буквально превращался в карателей, бесцеремонно разбиравшийся с членами семей, родственниками, односельчанами мятежников. Это подкрепляло мятежные настроения и прибавляло восставшим сторонников.

В результате вооруженного восстания во многом было отсрочено форсирование сплошной коллективизации.

В законодательство республики были введены новеллы. Так, в частности, в Уголовным законе появилась статья о государственный преступлениях. Согласно статье 41 , за организацию вооруженного восстания с целью «нисповреждения установленного основными законами образа правления, захват власти...» наказывалось расстрелом с конфискацией имущества (НА РТ, ф. 93, оп. 1, д. 13, л. 6). Партия усилила работу по отделению церкви от государства. Помимо экономических (налогооблажения, секуляризации) и политических (лишение избирательных прав) мер, большое внимание было уделено атеистической пропаганде.

Вооруженное восстание в Туве также, как и в Монголии, продолжилось вплоть до 1933 г. В Туве очаги сопротивления периодически фиксировались в отдельных районах Тувы (1931 г. - Ужар-Даге, 1932 г. Тере-Холе, 1933 г. - Дус-Даге). 


\section{Благодарности}

Выражаю благодарность научному сотруднику группы истории ТИГПИ при Правительстве Республики Тыва А. А. Асонычеву за помощь в подготовке карты.

\section{СПИСОК ЛИТЕРАТУРЫ}

История Тувы (1964) : в 2 т. / отв. ред С. К. Тока. Новосибирск : Наука. Т. II. 455 с.

История Тувы (2007) / гл. ред В. А. Ламин. Новосибирск : Наука. Т. II. 428 с.

Кузьмин, С. Л., Оюунчимэг, Ж. (2015) Вооруженное восстание в Монголии в 1932 г. М. : МБА. 212 с.

Кузьмин, С. Л. (2016) О роли иностранных влияний на восстания против строительства социализма в Монголии // Научный диалог. № 1 (49). С. 225-233.

Мачавариани, В., Третьяков, С. (1930) В Танну-Туву. М. ; Л. : Молодая гвардия. 98 с.

Монгуш, М. В. (2001) История буддизма в Туве. Новосибирск : Наука. 200 с.

Основной закон (Конституция) Тувинской Аратской Республики (1932) : перев. с тув. яз. Кызыл : Тьва kугуnеnin nom cogaadbr ceri. $16 \mathrm{c}$.

Отрощенко, И. В. (2012) Из истории протестного движения в ТНР первой половины 1930-х гг. [Электронный ресурс] // Новые исследования Тувы. № 3. C. 74-85. URL: https://nit.tuva.asia/nit/article/view/315 (дата обращения 03.05.2020).

Очерки истории Тувинской организации КПСС (1975) / В. Ч. Очур, О. А. Толгар-оол, Ю. Л. Аранчын и др.; ред. коллегия: Г. Ч. Ширшин (отв. ред.) и др. Кызыл : Тувинское книжное издательство. 405 с.

Саaя, С. В., Сат, С. Ч. (2006) Геополитический статус Тувы в первой половине XX века (1911-1944 годы). Абакан : Хакасское книжное издательство. 293 с.

Сердобов, Н. А. (1985) Коминтерн и революционная Тувы. Кызыл : Тувинское книжное издательство. 238 с.

Дата поступления: 02.06.2020 г.

\section{REFERENCES}

Istoriia Tuvy [The History Of Tuva] (1964): in 2 vols. Moscow, Nauka. Vol. II / ed. by S. K. Toka. 455 p. (In Russ.).

Istoriia Tuvy [The History Of Tuva] (2007): in 3 vols. / ed. by V. A. Lamin. Novosibirsk, Nauka. Vol. 2. 430 p. (In Russ.).

Kuz'min, S. L. and Oiuunchimeg, Zh. (2015) Vooruzhennoe vosstanie v Mongolii v 1932 g. [Armed revolt in Mongolia in 1932]. Moscow, MBA. 212 p. (In Russ.).

Kuz'min, S. L. (2016) O roli inostrannykh vliianii na vosstaniia protiv stroitel'stva sotsializma v Mongolii [On the role of foreign influences on rebellions against socialism building in Mongolia]. Nauchnyi dialog, no. 1 (49), pp. 225-233. (In Russ.).

Machavariani, V., Tret'iakov, S. (1930) V Tannu-Tuvu [To Tannu-Tuva]. Moscow, Leningrad, Molodaia gvardiia. 98 p. (In Russ.).

Mongush, M. V. (2001) Istoriya buddizma v Tuve (vtoraya polovina VI - konets XX v.) [The History of Buddhism in Tuva (latter half of the 6th - late 20th cc.)]. Novosibirsk, Nauka. 200 p. (In Russ.).

Osnovnoi zakon (Konstitutsiia) Tuvinskoi Aratskoi Respubliki [Basic law (Constitution) of the Tuva Arat Republic] (1932). Transl. from Tuv. Kyzyl, Tuvan book publishing house. 16 p. (In Russ.).

Otroshchenko, I. V. (2012) Iz istorii protestnogo dvizheniia v TNR pervoi poloviny 1930-kh gg. [About the history of protest movement in People's Republic of Tuva in the first half of 1930's]. New Research of Tuva, no. 3, pp 74-85 [online] Available at: https://nit.tuva.asia/nit/article/view/315 (access date 03.05.2020). (In Russ.).

Ocherki istorii Tuvinskoi organizatsii KPSS [Essays on the history of Tuvan branch of the CPSU] (1975) / [V. Ch. Ochur, O. A. Tolgar-ool, Yu. L. Aranchyn et al., editorial board: G. Ch. Shirshin (ed.) et al.]. Kyzyl, Tuvan book publishing house. 405 p. (In Russ.).

Saaia, S. V. and Sat, S. Ch. (2006) Geopoliticheskii status Tuvy v pervoi polovine XX veka (1911-1944 gody) [Geopolitical status of Tuva in the first half of the twentieth century (1911-1944)]. Abakan, Khakass book publishing house. 293 p. (In Russ.).

Serdobov, N. A. (1985) Komintern i revoliutsionnaia Tuva [The Comintern and the revolutionary Tuva]. Kyzyl, Tuvan book publisher. 238 p. (In Russ.). 